\title{
Semantics of Symbolic Decoration on Macedonian Traditional Movable Furniture from $19 t h$ Century
}

\section{Semantika simboličkih ukrasa na makedonskome tradicionalnom pokretnom namještaju iz 19. stoljeća}

\author{
Professional paper • Stručni rad \\ Received-prispjelo: 21. 1. 2015. \\ Accepted-prihvaćeno: 5. 5. 2016. \\ UDK: $630 * 836.1$ \\ doi:10.5552/drind.2016.1505
}

\begin{abstract}
The analysis of symbolic decoration on movable furniture is a process defined by expressing the inner world of thoughts and ideas through the outside, living world. The furniture and other household equipments were made with high functionality. Functionality of the furniture was the most important, more precisely its aestetics was a result of functionality. The world of the symbolic decoration was personal, intimate or beloged to the family, and although it was conceived and handmade by self-taught carpenter/the host, analyses reveal deep cosmological links of images with the past and tradition. Therefore, the aim of this paper is to analyze the process of creating the decoration and semantics of the Macedonian traditional movable furniture from the 19th century. Researches and analyses were made in the Republic of Macedonia, more specifically in several villages around the mountain of Skopska Crna Gora and in the village Dzepciste from the Tetovo region, and the region of the citty of Veles. Based on measurements of the objects, photos, drawings, foto-documentation, the paper exposed their actual appearance. Based on these drawings, analyses of symbols and forms were made, as well as a deeper analysis of the religious context within which they were made. The analyzes showed that the symbolic decoration of movable furniture in the Macedonian traditional house from the 19th century has its roots in the past as the archetypal signs follow the furniture through the ages. The purpose of this paper was to analyze cosmological pictures of the furniture, to describe them clearly and in the future perhaps be able to apply them in a new modern context.
\end{abstract}

Key words: semantic, symbolic decoration, antique context, Christian context, identification, formalization, cosmological character of decoration, expression, traditional furniture.

SAŽETAK • Analiza simboličkih ukrasa na pokretnom namještaju proces je definiran izražavanjem unutarnjeg svijeta misli i ideja prema vanjskome, živom svijetu. Namještaj i ostali proizvodi i uređaji za kućanstvo proizvedeni su tako da budu što funkcionalniji. Funkcionalnost namještaja je najvažnija, a njegova je estetika rezultat funkcionalnosti. Svijet simboličkih ukrasa najčešće je bio osobna, intimna ili obiteljska odrednica, a rezultat je

\footnotetext{
${ }^{1}$ Author is associate professor at Faculty of Design and Technology of Furniture and Interiors, Ss. Cyril and Methodius University, Skopje, Republic of Macedonia.

Autorica je izvanredna profesorica Fakulteta za dizajn i tehnologiju namještaja i interijera, Sveučilište svetog Ćirila i Metoda, Skopje, Republika Makedonija.
} 
maštovitosti i rada samoukih stolara. Analize otkrivaju duboke kozmološke veze sa slikama iz prošlosti i tradicijom te njihovo ponavljanje u povijesti. Stoga je cilj ovog rada bio analizirati proces stvaranja ukrasa i semantiku makedonskoga tradicionalnog pokretnog namještaja iz 19. stoljeća. Istraživanja i analize obavljeni su u Republici Makedoniji, u nekoliko sela oko planine Skopska Crna Gora, zatim u selu Dzepciste, u regiji oko grada Tetova te u području grada Velesa. Na temelju mjerenja objekata, fotografija, crteža i fotodokumentacije, u radu je izložen njihov pravi i stvarni izgled. Na temelju tih crteža obavljene su analize simbola i oblika te dublje analize religijskog konteksta pod utjecajem kojega su ti ukrasi nastali. Analize su pokazale da simbolički ukrasi pokretnog namještaja u makedonskoj tradicijskoj kući iz 19. stoljeća ima korijene u prošlosti, unutar koje se na temelju arhetipskih znakova može pratiti razvoj namještaja kroz stoljeća. Cilj rada bio je jasno opisati analizu kozmološke slike namještaja i tu sliku nekad u budućnosti možda prenijeti u novi, moderni kontekst.

Ključne riječi: semantika, simbolički ukrasi, antikni kontekst, kršćanski kontekst, identifikacija, formalizacija, kozmološko obilježje ukrasa, izražavanje, tradicionalni namještaj

\section{INTRODUCTION}

\section{UVOD}

\subsection{Historical aspect}

1.1. Povijesni aspekt

Symbolic decoration on movable furniture is a process defined by expressing the inner world of thoughts and ideas through the outside, living world. For the local craftsman, the only way to recognize what part of the world different crafts come from was through identification. Identification was achieved through interference between the complexes of experiences linked to a certain existential sphere, and some elements or occurrences from the person's immediate surroundings, all of this deriving from the person's archaic consciousness (Nikoljski, 2013).

This paper differentiates the antique and the Christian contexts, these two being the basic expression topics of people living in this area for the analyzed period of time. It can be obviously concluded that both the antique and the Christian contexts have left significant imprints on cosmological images and performances of both movable and built in furniture in Macedonia, during the 19th century (Causidis, 2008).

The process of decoration has always begun with the three dimensional geometric projections of the cosmic space and shape, because these are the basic images that people have unconsciously reinterpreted again and again in the form of decoration on the furniture surface.

Researching decorative semantics and the selftaught craftsman's need to express himself through drawing on, engraving and carving the furniture, it is exstremely easy to notice people's need to decorate their surroundings. Various examples have shown that the methods for designing hand-made furniture are often used for the same type of expression (Nikoljski, 2009).

\section{MATERIAL AND METHODS}

\section{MATERIJAL I METODE}

\subsection{Methods of historical research}

2.1. Metode povijesnog istraživanja

\subsubsection{Religion's impact on decoration}

2.1.1. Religijski utjecaj na dekoracije

The horizontal projections of the cosmos on everyday appliances and furniture in antiquity (the second half of the first millennium B.C. until the first half of the first millennium A.D.), were projected in two different ways:

- more often as an artistic embellishment of the objects, delivered through geometric and figural motifs.

- less often as basic geometric concepts of the objects or compositions.

With the establishment of the Eastern Roman Empire, especially with the recognition and spreading of the new religion, the Balkan and the Mediterranean regions started to adopt a new aspect of understanding of the universe, which science now classifies as being "typical for the spirit of the Orient." Starting in the 3rd century A.D. and continuing throughout the following centuries, this tendency, in its ultimate instance, has been manifested in the Christian cosmological scheme.

In the concept of Christianity, it had been more important to understand the cosmos through its opposing hierarchal systems, such as: "above heavens" - "below heavens", "light" - "darkness", "pure" - "heathen", "this time" - "that time", and moreover between the categories "sacred" - "profane" or more accurately "sacred - most sacred"(Causidis, 2008).

Still, as opposed to the antique cosmological models, the Christian model, being in denial of its spherical shape, portrayed the cosmos in a quadrilateral form.

\subsubsection{The impact of the Christian quadrilateral cosmic model}

2.1.2. Utjecaj kršćanskoga četverokutnog kozmičkog modela

The geographical core of the cosmic space models in the Christian world originates from the regions of Asia. The ancient Chinese portrayal of space is the most accurate one compared to our idealized model. It portrays the Earth as a flat board, or a pyramid. It is fixed and surrounded by sea. Above it, there is a round, dynamic sky. For example, two of these authentic models are manifested in Mandalas and in stoups (Causidis, 2008).

Of course, the portrayal of this idealized model on both the geometrical and figural levels has been brought up as an artistic ornamentation of decorations and decorated surfaces of the movable furniture. The local craftsman's need to express himself through channeling the inner world of thoughts and ideas to 
the outside has occurred through two processes, which, although seemingly subsequent to one another, are actually synchronized, mutually intertwined and inseparable. These processes are identification and formalization.

\subsection{Methods of research with identification of} semantic concepts

2.2. Metode istraživanja s identifikacijom semantičkih koncepata

The act of relating to or identifying things is the basic concept of understanding the world around us. Identification is achieved through interference between the complexes of experiences linked to a certain sphere of the macro-cosmological existence, and some elements or occurrences from the person's immediate surroundings. In this process, the surrounding occurrences have the following characteristics, or in other words, they need to be:

- initiators of the given occurrence in the macro-cosmos (this piques interest),

- a key for permeation into its essence (which leads to reasoning),

- an element that completes the perception of the occurrence (this process leads to recognition),

- an element that would export the perception of the occurrence outside of the subconscious (which initiates presentation), and

- a factor for presenting personal perceptions onto other units of the given cultural complex, which initiates communication (Causidis, 2008).

Thus, the concept of identification is the basic concept of presentation and understanding space.

With the development of rational human consciousness, the degree of correlation between what is identified (for example some occurrences in the macrocosmos) and its identifier (the symbols) decreases, which causes the process of intertwining to transition from the cognitive sphere into the sphere of styles and forms (recognized in the symbolic and artistic context).

\subsection{Formalization}

\subsection{Formalizacija}

The perception of the shape of the macro-cosmos, or the formalization, begins with its identification, and it is usually linked to a certain symbol, a.k.a. an identifier. In the archaic consciousness of our people, this process did not just start with the perception of ideas, but also with the perception of forms.

To analyze the aspect of forms and shapes of the macro-cosmos means to analyze the levels of its shape, which are based on the primary impressions of space that the archaic consciousness has created.

The observations presented in this thesis, which refer to furniture decoration in a restored Macedonian house of the 19th century, are in close correlation with the aspects of space. On one hand they result from these aspects, but on the other hand they define them to a large degree, and thus they shed light on human relations with this most abstract level of existence of the universe.

\section{RESULTS AND DISCUSSION}

\section{REZULTATI I RASPRAVA}

\subsection{Cosmological character of decoration}

3.1. Kozmološko obilježje dekoracije

The cosmos is presented on various objects from the material culture, such as everyday objects, furniture, fabrics, bed sheets and jewelry, in two ways:

- embedded in the basic geometric composition of furniture,

- as an artistic decoration of furniture using geometric and figural motifs.

As opposed to architecture, the cosmological nature of the pictures represented in this cultural sphere (on movable furniture and household furnishing) is much harder to prove. This is mainly because of the fact that the sphere they belong to is not as accessible as the architectural one. Quite the contrary - they are much more intimate and personal, and because of that, they are much less affected by canons of the official ideology. The transposition of the spiritual in the artistic elements on furniture had been accomplished using a smaller degree of control coming from the codified spiritual and religious systems. Thus, it had been largely influenced by spontaneity and collective work of people. In these frameworks, the creators' freedom to invent played a big role, whether it came from amateur authors and craftsmen, self-taught villagers and carpenters, or even professional craftsmen of certain crafts and artists (Nikoljski, 2009).

Because of their nature, the cosmological images that decorate furniture and everyday objects are presented without the accompanying verbal context, so that the discovery and interpretation of their cosmological dimension is nowadays conducted painstakingly, using complex scientific methodology. Due to their complex nature, and because of the small degree of previous exploration and lack of literature and material data, decoration on furniture from this period was analyzed very carefully, gradually and precisely.

\subsection{Concentric organization of cosmic zones}

3.2. Koncentrična organizacija kozmičkih zona

The former cosmological character of ornamental compositions present on movable furniture is indicated by the use of motifs and their layout, despite their non-preserved narrative context. Illustration-example is shown in Fig. 1 and Fig. 2. With movable furniture from the 19th century Macedonian house, the concept of concentric organization of the cosmic zones was usually followed in the following order:

- The Earth is represented by the ornamented zones that cultivate the rectangular composition and appears in the form of an external and internal border - a continuation of lozenge-shaped forms.

- The link between the lozenge shape and the Earth is rooted in its Christian cosmological model, whose geometric shape is square. In this model, a given area on the Earth, seen when standing on it, resembles a rhombus (a square seen in perspective). It is the lozenge shape that is often seen in carvings on movable furniture, especially on dressers and chests. 
- The continuation of round motifs laid out between the rhombs often symbolizes the Earth's center or core, but could also be interpreted as the latent presence of vegetation, or the vegetative force in the Earth's womb.

- The aboveground level is represented by four schematically arranged plants, or with the help of triangles symbolizing houses. However, this is not the only interpretation of triangles, as they nurture different layers, starting with a female system, fertility, a home or a house.

- The sky is represented through the middle area as well as the central rosette, which has a clear morphological relationship with the sun. Originally it could have represented the whole sky as a circle. In addition to this representation of the sky, two three-legged swastikas joined by crescent-shaped motifs (crescent moons) represent the solar and lunar cycles (Gavazzi, 1996).

All of these shapes can be found in carved decoration on movable furniture, while the rosettes are usually a centerpiece and are located in the middle of the front side of the chest or dresser.

\subsection{Geometry in movable furniture design}

3.3. Geometrija u dizajnu pokretnog namještaja

The transition from two-dimensional to three-dimensional geometric displays of space had been very logical for contemporary culture representatives, as well as for contemporary furniture design. This is a result of the fact that they are the most accurate, immediate and objective projections. Analyzing the historical aspect of furniture decoration in the revived Macedonian house from the 19th century, these clean and abstract geometric manifestations usually represent the long-gone stadiums of the mythological symbolic design of space (Fig. 1. and Fig. 2).

Their appearance can be defined as a process of gradual reduction of all that is geometric, or more precisely, getting rid of the material cosmic models in which the geometric aspect is always implicitly embroidered.

\subsection{Most common geometric forms \\ 3.4. Najčešći geometrijski oblici}

In the area of geometric decoration, the following forms and shapes are usually encountered on the furniture in Macedonian houses:

\section{A quadrilateral}

A quadrilateral with an inscribed circle or a quadrilateral with a described circle. The quadrilateral symbolizes the Earth, and the round rosettes symbolize the sky. Therefore, both feminine and masculine principle can be seen (Fig.1).

\section{A trapezoid}

As a quadrilateral, the trapezoid falls in the category of geometrical representatives of the lower levels of space. According to one analogy, this means that the trapezoid has probably emerged as a product of a transformation of the triangle. Another one claims that when the rectangular shape of the Earth is seen in perspective, it looks like a trapezoid. (Fig.1).
The trapezoid symbolizes the mother-earth or woman-earth relationship.

\section{A circle}

The circular segments in the shape of cut-outs or parts of the circle - could have represented the sides of the world, or maybe even the phases of the solar cycle. (Fig.1).

The rosette-like cut-outs in the circles represent the phases in which the sun rotates around the Earth.

The concentric circular zones found in the decoration of some furniture represent a two-dimensional projection of the three-dimensional model of the cosmos, mimicking a sphere made of several sub-spheres moving concentrically one into another. However, this spherical representation of the cosmos is not accepted among our people, because it is considered to be pagan. Instead, it has been opposed by the widespread "quadratic-circular" Christian model, nurtured by the craftsmen in the area.
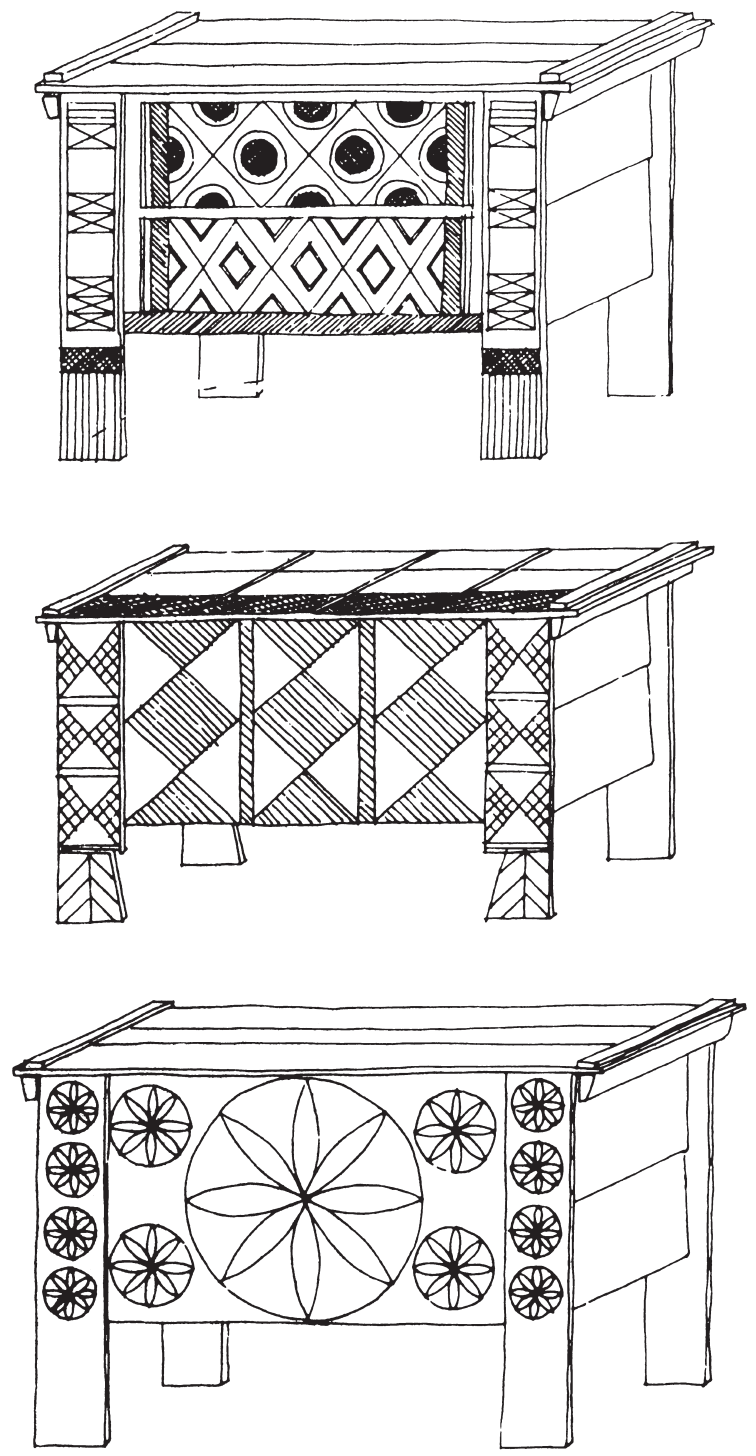

Figure 1 Carved decoration with geometrical inspiration on movable furniture, Villages of Skopska Crna Gora ${ }^{1}$ Slika 1. Geometrijski inspirirani ukrasi urezani na pokretnom namještaju (sela u području planine Skopska Crna Gora) 


\section{A triangle, a rhomb}

In the Slavic cultural complex, these iconographic elements - despite their archaic meanings which have always been linked to the female body, or women's clothing - could also have induced a second, cosmological meaning, linked to the Earth as a cosmic element, while the rhombic and triangular ideograms have accented the Earth's fertility, alluding to the female organs, or the plots and fields that the Earth is separated into. (Fig.1).

\subsection{Interaction between anthropomorphic and geometrical decoration}

3.5. Interakcija između antropometrijskih i geometrijskih ukrasa

On a geometrical level, metamorphosis is manifested as a process of interaction between the female figure and the basic geometric representations of the lower cosmic zones (rhombs, squares, rectangles, triangles, trapezoids and circles) or the more complex geometric ideograms deriving from them (Fig. 1, Fig. 2). The intensity of the anthropomorphic and geometric impression on a mythological image is in perfect balance, so that it can be categorized equally as a geometric product of the anthropomorphic images and the opposite, an anthropomorphic product of geometric images. The interaction between the anthropomorphic and geometric is also motivated by the animistic perception of the world, which is inherent in the archaic consciousness. The concept of an animistic perception of the world, as a global trans-historic and trans-cultural phenomenon, appears independently at the same time in the archaic cultures from different centuries and parts of the world.

\subsection{Stylization of vegetative and zoomorphic forms}

3.6. Stilizacija biljnim i zoomorfnim oblicima

Throughout the history of decoration, phytomorphological images often appear. They often symbolize the relation of the woman in childbirth with the Earth (mother-Earth). In this equalization, the plants, especially the weeds, symbolize the woman's hair. Among Slavic peoples, there is a popular belief that "the one who pulls weeds, pulls the hair of his or her mother." This symbolical identification is the base for the green hair that fairies and pixies are known for, and maybe even the fact that in Roman culture, women thanked Venus for their hair. In South Slavic tradition, these mythologems resonate the name Biljana (a personal name coming from the word "bilje" or herbs), often represented in traditional songs (Causidis, 2008).

The phytomorphization can include all of the female figure, turning her into a plant, so that her torso adopts the role of a trunk, her extremities adopt the form of bent branches, leafs or tendrils, while the neck and head take on the role of the flower's bud or blossom (Fig. 2).

The motifs become a part of the mythological, symbolic and artistic sphere. As in the concept of

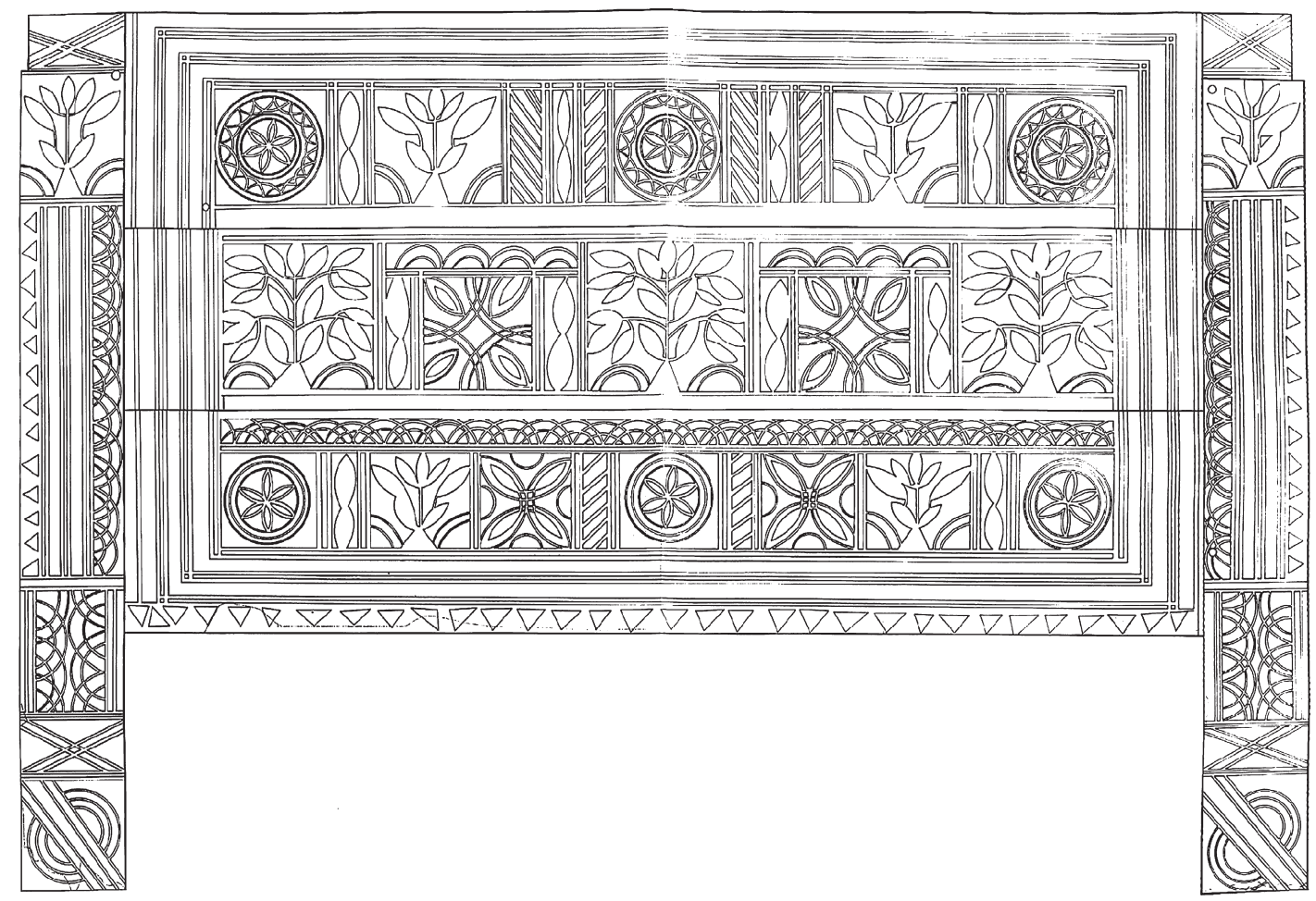

Figure 2 Carved decoration with a combination of geometrical and floral motifs on movable furniture, village of Dzepcishte, Tetovo $^{1}$

Slika 2. Urezani ukras: kombinacija geometrijskih i cvjetnih motiva na pokretnom namještaju (selo Dzepciste, Tetovo)

\footnotetext{
${ }^{1}$ The drawing is taken from the collection composed for the project "EtnoPredmeti", for the Interior Architecture subject, 1993-2003, Faculty of Architecture, Skopje
} 

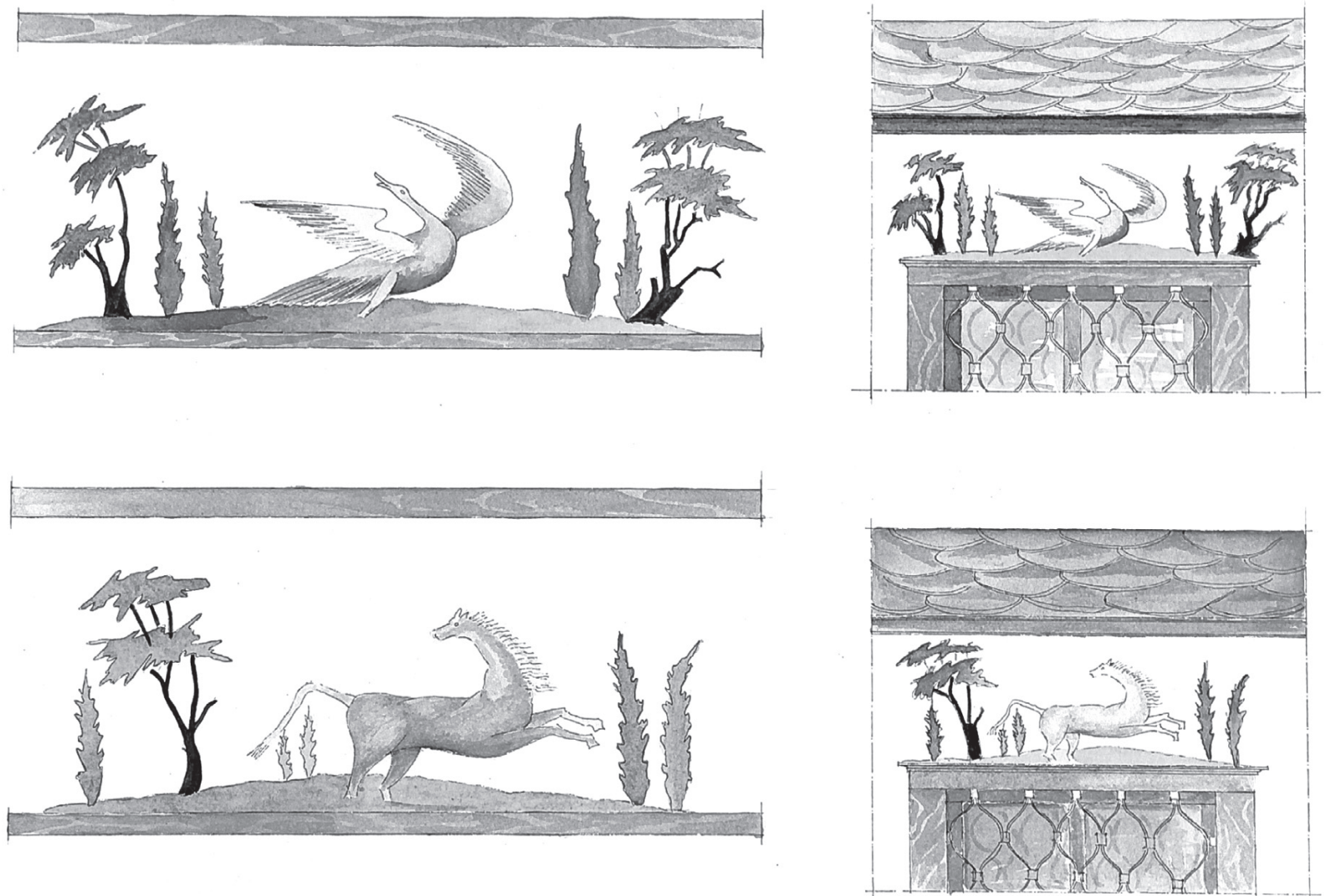

Figure 3 Decoration made by drawing, oilcolor painting, zoomorfic motifs, on house furniture in Veles ${ }^{1}$

Slika 3. Ukrasni crteži - zoomorfni motivi na namještaju izvedeni oslikavanjem uljnim bojama (kuća u Velesu)

supplementation, the partial and global phytomorphization of the female figure has a role of connecting her with the lower zones and elements of space (the Earth, the underground, the water) and to present the macro-cosmic aspect of what is feminine (Fig. 2). This primarily includes the birthing power of plants, but also all the other abstract categories that plants symbolize (fertility, food, life, abundance, and vital cycles in nature and humans). These types of images are the most frequent when it comes to furniture decoration. It is exactly their hyper-productivity that has contributed to the large degree of transformation of their primary prototypes, especially in the direction of their complete ornamentation. As a result, a particular issue today is whether or not a certain image of this type has kept its original mythologicalsymbolic meaning and according to which measurement, and whether the extreme intensity of phytomorphization of these images always reflects a high degree of their demythologization.

The examples of furniture and furnishings discover that even though the complicated ornamentation with plants keeps evolving around the old compositional scheme given by the female figure as it was known in the past, it is not of great importance for it to maintain a symbolic connection to the female figure or the categories that she represents, especially on a level of conscious findings, while on a functional level, i.e. in the sacral-magical character of ornaments, in some cases that connection is very important.

\subsection{Zoomorphic decorative images}

3.7. Zoomorfne ukrasne slike

The specific manifestation of the zoomorphic forms-pictures, present in the form of carvings and paintings on furniture, could not always be generalized, especially because of the local specifications of some specific ecological ambiance in which a zoological-cosmological symbolic relation like this has been born in and existed at some point. For a large part of mankind, the most frequent and universal are aquatic animals as well as reptiles, which usually represent water and soil, or the underground, and the lower zones of Space. At least in our territory and even further, this symbolic process is mostly represented by fish, snakes, lizards, frogs and turtles (Fig. 3).

\section{CONCLUSION}

\section{ZAKLJUČAK}

To understand the relationship between an individual and his/her surroundings, it is necessary to make a quick differentiation between the antique and the Christian contexts of this relationship. It can be obviously concluded that both the antique and the Christian contexts have left significant imprints on the cosmological images and performance of both movable and built-in furniture in Macedonia during the 19th century. The process of decoration has always begun with the three dimensional geometric projections of the cosmic space and shape, because these are the basic im- 
ages that people have unconsciously reinterpreted again and again in the form of decoration on the furniture surface.

The horizontal projections of the cosmos on everyday appliances and furniture in antiquity (the second half of the first millennium B.C. until the first half of the first millennium A.D.), were projected in two different ways: more often as an artistic embellishment of the objects, delivered through geometric and figural motifs, and less often as basic geometric concepts of the objects or compositions. With the establishment of the Eastern Roman Empire, especially with the recognition and spreading of the new religion, the Balkan and the Mediterranean regions started to adopt a new aspect of understanding the universe, which science now classifies as being "typical for the spirit of the Orient." Starting in the 3rd century A.D. and continuing throughout the following centuries, this tendency, in its ultimate instance, has been manifested in the Christian cosmological scheme.

Thus, the concept of identification is the basic concept of presentation and understanding space.

With the development of rational human consciousness, the degree of correlation between what is identified (for example some occurrences in the macrocosmos) and its identifier (the symbols) decreases, which causes the process of intertwining to transition from the cognitive sphere into the sphere of styles and forms (recognized in the symbolical and artistic context).

When it comes to horizontal cosmological projections, it can be sais that they have survived in a lot of archaic forms, where they can be found on some pieces of movable furniture, (mostly chests, dressers and nightstands), in the form of artistic manifestations or carvings on the wood. Some everyday use objects such as textile, small wooden and ritualistic objects, are also decorated using horizontal cosmological projections.

The need for geometric display of cosmological pictures and cosmic phenomena in the form of decoration on furniture surface probably occurred as a result of a few factors:

- insufficient knowledge of primitive craftsman about art and artistic display of objects and occurrences;

- the need to accentuate the cosmological character of objects (figures);

- the acknowledgement of inherited and traditionally reinterpreted symbols.

The implementation of decorative wood carving and textile knitting made it easier for the craftsmen and women to display these symbols and designs on furniture.

From the geometric decoration aspect, the following forms and shapes are usually encountered on the furniture in Macedonian traditional houses from the 19-th century: quadrilateral, trapezoid, circle, triangle, and rhomb.

The phytomorphization can include all the female figure, turning her into a plant, so that her torso adopts the role of a trunk, her extremities adopt the form of bent branches, leafs or tendrils, while the neck and head take on the role of the flower's bud or blossom (Fig. 2).

The motifs that develop this process become a part of the mythological, symbolic and artistic sphere. As in the concept of supplementation, the partial and global phytomorphization of the female figure has a role of connecting her with the lower zones and elements of space (the Earth, the underground, the water) and to present the macro-cosmic aspect of what is feminine (Fig. 2). By analyzing the examples of furniture and furnishings, it has been discovered that even though the complicated ornamentation with plants keeps evolving around the old compositional scheme given by the female figure as it was known in the past, it is not of great importance for it to maintain a symbolic connection to the female figure or the categories that she represents, especially on a level of conscious findings, while on a functional level, i.e. in the sacralmagical character of ornaments, in some cases that connection is very important.

The most frequent and universal for a large part of mankind are aquatic animals as well as reptiles, which usually represent water and soil, or the underground, and the lower zones of Space. At least in our territory and even further, this symbolic process is mostly represented by fish, snakes, lizards, frogs and turtles (Fig. 3).

\section{REFERENCES}

5. LITERATURA

1. Aleksievska, H. J., 1984: Likovni i oblikovni vrednosti na narodnata arhitektura kako rezultat na praktičnata graditelska postapka. Zbornik na Arhitektonskiot fakultet, 7, Skopje, p. 53-60.

2. Čausidis, N., 1994: Mitskite sliki na Juznite Sloveni, Skopje. Kosmoloshki sliki 2008: Skopje, 96.

3. Čausidis, N.; Lilcic, V.; Senjrafimova, A.; Aleksiev, E., 1995: Makedonija kulturno nasledstvo, Skopje.

4. Gavazi, M., 1996: Simbolikata na trikselot i svastikata, zbornik trudovi. Institut za folklor „Marko Cepenkov“, Skopje.

5. Golomb, Z., 1959: Genetiski vrski megju karpatskata i balkanskata stolarska terminologija i ulogata na slovenskiot element vo ova podracje, MJ, X, knj.1-2, Skopje.

6. Nikoljski, E., 2010: Integration between build in and freestanding furniture in Macedonian house from 19 century and possibility for continuity in contemporary furniture design, chapter 5. Methods of technical processing of furniture, p. 96-122.

7. Nikoljski, E., 2013: Free standing furniture in a traditional Macedonian house from the 19th century. Wood technology \& Product design International scientific conference, Proceedings, Vol. 1, Skopje, 2013.

8. Svetieva, A., 1979: Solarnite motivi vo makedonskata plastićna ornamentika na tavanite i vratite. Makedonski folklor, XII, 23, Skopje.

9. Tozi, N., 1969: Kukurekot vo ornamentikata na mijaćkite kopanichari. Makedonski folklor, II, 3-4, Skopje, p. 407411.

10. Volinjec, R., 1972: Selo Bituse - Starata arhitektura, nejzinite vrednosti i perspektivi. Selska arhitektura, zashtita i revitalizacija, Debar, p. 53-64. 
11. Volinjec, R.; Aleksieva, J., 1984: Likovni i oblikovni vrednosti vo narodnata arhitektura kako rezultat na praktićnata graditelska postapka. Zbornik na Arhitektonskiot fakultet, 7, Skopje, p. 53-60.

12. *** 1987: Orientalni belezi vo makedonskata rezba (tavani, dolapi i vrati). Makedonski folklor, XX, p. 39-40, Skopje.

13. ***1983: Pokućninatavo Makedonija. Etnološki muzej na Makedonija, Skopje.

14. ***1963: Pokućninata vo starata selska kuća vo Makedonija. Godishen zbornik na Tehnickiot fakultet, V, 5, p. 33-47, Skopje.

15. ***1992: Rezbareni tavani, dolapi i vrati vo Makedonija. Institut za folklor „Marko Cepenkov“, Skopje.

\section{Corresponding address:}

Assoc. Prof. ELENA NIKOLJSKI PANEVSKI, Ph.D.

Faculty of Design and Technologies of Furniture and Interior

Bul. Aleksandar Makedonski bb

PO box 8,1130, Skopje

MACEDONIA

e-mail: nikoljski@fdtme.ukim.edu.mk 